\title{
RUANG AJAR BALANG: FASILITAS EDUKASI PEMANFAATAN DAN PENGOLAHAN ECENG GONDOK DI SUNGAI SIAK
}

\author{
Vellisa $\mathrm{Chou}^{1)}$, Djidjin Wipranata ${ }^{2)}$
}

\author{
1)Program Studi S1 Arsitektur, Fakultas Teknik, Universitas Tarumanagara, vellisac24@gmail.com \\ 2) Program Studi S1 Arsitektur, Fakultas Teknik, Universitas Tarumanagara, djidjinellya@yahoo.com
}

\begin{abstract}
Abstrak
Berdasarkan data yang dilansir dari Pusat Data dan Informasi Kementerian Pertanian (Kementan 2019), Provinsi Riau merupakan penghasil kelapa sawit terbesar di Indonesia dengan luas mencapai $2.430,51$ ha dan produksi mencapai rata-rata 8.605,65 ribu ton setiap tahunnya. Namun, tingginya aktivitas industri sawit menyebabkan rusaknya ekosistem yang berada di sekitar sungai akibat pembuangan limbah yang menyebabkan tingginya kandungan logam pada air dan pendangkalan di Sungai Siak. Maka dari itu perlu dilakukan penanggangan berupa pengolahan air limbah dengan biofiltasi alami, salah satunya adalah dengan eceng gondok. Selain ekonomis, tumbuhan air ini memiliki potensi perkembangan yang sangat cepat. Ruang Ajar Balang-balang merupakan pusat edukasi eceng gondok sebagai purifikasi logam berat di Sungai Siak, Riau. Proyek ini, memanfaatkan potensi eceng gondok sebagai biofiltrasi alami yang dapat mempurifikasi logam berat pada kandungan air di Sungai Siak sebesar 99,70\% (Rosida, 2018). Perkembangan eceng gondok yang pesat menjadi potensi bagi usaha kerajinan tangan dan instalasi ruang. Dengan demikian perkembangan eceng gondok dapat dikendalikan sehingga tidak mengganggu aktivitas pengolahan air limbah. Pada perancangan proyek ini menggunakan penggabungan metode perancangan lokalitas dan kontekstual diharapkan proyek dapat memiliki unsur serasi dan seimbang terhadap lokalitas di Kabupaten Siak. Hadirnya Ruang Ajar Balang-balang diharapkan menjadi fasilitas yang dapat mengedukasi masyarakat terhadap potensi eceng gondok sebagai purifikasi logam berat dan manfaat ekonomi yang dimilikinya.
\end{abstract}

Kata Kunci: eceng gondok; edukasi; purifikasi.

\begin{abstract}
According to data from the Data and Information Center of the Ministry of Agriculture (Kementan 2019), Riau Province is the largest palm oil producer in Indonesia with an area of 2,430.51 ha and an average production of 8,605.65 thousand tons annually. However, the high activity of the palm oil industry causes damage to the ecosystem around the river due to waste disposal which causes high metal contentin the water and siltation in the Siak River. Therefore, it is necessary to carry out handling in the form of wastewater treatment with natural biofiltration, one of which is water hyacinth. In addition to being economical, this aquatic plant has the potential to grow quickly. Balang-balang Learning Area is an educational center for water hyacinth as a heavy metal purification in the Siak River, Riau. In this project, utilize the potential of water hyacinth as a natural biofiltration that can purify heavy metals in the water content of the Siak River until 99.70\% (Rosida, 2018). The growth of water hyacinth has become a potential for handicraft businesses and space installations. Therefore, the growth of water hyacinth can be controlled so that it does not interfere with wastewater treatment activities. In designing this project using a combination of locality and contextual design methods, it is hoped that the project can have elements of harmony and balance with localities in Siak Regency. The presence of the Balang-balang Learning Area is expected to be a facility that can educate the public on the potential of water hyacinth as a heavy metal purifier and its economic benefits.
\end{abstract}

Keywords: education; purification; water hyacinth. 


\section{PENDAHULUAN}

\section{Latar Belakang}

Sungai Siak berada di Provinsi Riau merupakan sungai terdalam di Indonesia. Kedalamannya dapat mencapai 30 meter dengan panjang 300 kilometer sehingga dahulunya sungai ini merupakan jalur perdagangan dari Sumatera menuju pelabuhan antar bangsa di Malaysia karena dapat dilalui oleh kapal-kapal tanker. Namun akibat berkembangnya jumlah penduduk dan perkembangan industri sawit, mengakibatkan semakin berkembang kegiatan industri sawit di sekitar sungai sehingga menyebabkan pendangkalan oleh limbah kedalaman Sungai Siak sehingga sekarang hanya mencapai 18-20 meter (Ariful, 2017). Tingginya aktivitas industri sawit di sekitar Sungai Siak menyebabkan rusaknya ekosistem yang berada di sekitar sungai, sehingga dapat mengakibatkan tercemarnya habitat alami dan bermacam-macam ikan khas Riau akibat limbah logam berat. Menurut Budijono et al (2017) Sungai Siak sudah tercemar logam berat sebesar $0,211 \mathrm{mg} / \mathrm{L}$.

Logam berat memiliki sifat mudah mengikat bahan organik, sehingga logam berat lebih banyak mengendap dan menumpuk di dasar perairan. Hal tersebut menyebabkan ikan-ikan di perairan Sungai Siak berpeluang besar terkontaminasi logam berat. Kandungan logam berat $\mathrm{Pb}$ pada daging ikan Juaro (ikan khas Riau) sudah melewati batas baku mutu yang ditetapkan oleh SNI 7387:2009 (BSN, 2009). Dari penelitian, kandungan logam berat $\mathrm{Pb}$ pada daging ikan terdapat $2,352 \mathrm{mg} / \mathrm{kg}$. Tingginya kandungan logam berat $\mathrm{Pb}$ pada daging ikan Juaro diduga karena ikan tersebut telah lama hidup dan berintereaksi dengan perairan yang tercemar logam berat $\mathrm{Pb}$ (Rosida, 2018).

Untuk itu dibutuhkan sebuah fasilitas yang dapat mewadahi fungsi pengolahan air limbah dan juga dapat mengedukasi masyarakat mengenai peran penting eceng gondok sebagai biofiltrasi alami. Dengan fasilitas ini diharapkan dapat menjadi solusi permasalahan Sungai Siak dan sekaligus membawa dampak peningkatan ekonomi bagi masyarakat sekitar.

\section{Rumusan Permasalahan}

Berdasarkan latar belakang diatas, maka rumusan masalah yang muncul adalah:

- Bagaimana desain yang diusulkan dapat menjadi wadah yang dapat berkontribusi dalam melampaui ekologi?

- Bagaimana program bangunan dapat memberikan solusi terhadap pencemaran air Sungai Siak yang disebabkan oleh limbah industri?

- Bagaimana proyek dapat memanfaatkan eceng gondok sebagai purifikasi logam berat?

- Bagaimana eceng gondok dapat diolah menjadi instalasi ruang dan usaha kerajinan tangan?

\section{Tujuan}

Berdasarkan rumusan masalah diatas, maka tujuan dari proyek ini adalah:

- Mencitapkan proyek dapat menjadi wadah yang berkontribusi dalam melampaui ekologi.

- Menciptakan proyek yang dapat memberikan solusi terhadap pencemaran air Sungai Siak yang disebabkan oleh limbah industri.

- Memanfaatkan eceng gondok sebagai purifikasi logam berat.

- Memanfaatkan eceng gondok sebagai instalasi ruang dan usaha kerajinan tangan.

- Menyediakan wadah bagi aktivitas yang berkaitan tentang pengolahan air Sungai Siak.

\section{KAJIAN LITERATUR}

\section{Arsitektur Ekologis}

Ekologi berasal dari bahasa Yunani 'oikos' dan 'logos', oikos berarti rumah tangga atau cara bertempat tinggal, dan logos berarti ilmu atau bersifat ilmiah. Ekologi didefinisikan sebagai ilmu 
yang mempelajari tentang hubungan timbal balik antara makhluk hidup dengan lingkungan di sekitarnya (Frick, 2007). Arsitektur ekologis merupakan pembangunan berwawasan lingkungan, dimana memanfaatkan potensi alam semaksimal mungkin (Titisari, 2012).

Menurut Yeang (2006), pendekatan desain ekologi dalam arsitektur didefinisikan dengan desain bioklimatis, desain dengan iklim lokalitas, dan desain rendah energi. Dengan demikian terdapat integrasi antara kondisi ekologi lokal, iklim mikro dan makro, kondisi tapak, program bangunan atau kawasan, konsep, dan sistem yang tanggap terhadap iklim, serta penggunaan energi yang rendah. Pendekatan ekologi dalam arsitektur yang lain yaitu menurut Heinz Frick (1998) adalah bahwa eko-arsitektur mencakup keselarasan antara manusia dan alam. Eko-arsitektur mengandung juga dimensi waktu, alam, sosio kultural, ruang dan teknik bangunan. Ekoarsitektur bersifat kompleks, mengandung bagian-bagian arsitektur biologis (kemanusiaan dan kesehatan), serta biologi pembangunan. Oleh sebab itu eko-arsitektur bersifat holistik dan mengandung semua bidang.

\section{Water Purification}

Water Purification atau Pemurnian air adalah proses menghilangkan bahan kimia yang tidak diinginkan, kontaminan biologis, padatan tersuspensi dan gas dari air yang terkontaminasi dengan tujuan untuk menghasilkan air yang sesuai demi keselataman dan peraturan pembuangan terpenuhi. Sistem pengolahan air limbah biologis dapat menjadi teknologi yang efisien dan ekonomis untuk memecah dan menghilangkan konsentrasi partikel tersuspensi.

\section{Pengolahan Biological Waste}

Salah satu pengolahan yang akan digunakan untuk kebutuhan permasalah di Sungai Siak adalah sistem pengolahan air limbah biologis Pengolahan limbah secara biologis adalah pengolahan menggunakan biota hidup atau mikroba yang mempunyai kemampuan untuk menguraikan dan membersihkan senyawa-senyawa polutan tertentu di dalam suatu reaksi biologis. Mikroorganisme ini memecah polutan organik untuk makanan, mereka saling menempel, yang menciptakan efek flokulasi yang memungkinkan bahan organik mengendap dari larutan. Ini menghasilkan lumpur yang lebih mudah dikelola, yang kemudian dikeringkan dan dibuang sebagai limbah padat.

Pengolahan air limbah biologis dapat dibagi atas tiga kategori utama, yaitu: aerobik, ketika mikroorganisme membutuhkan oksigen untuk memecah bahan organik menjadi karbon dioksida dan biomassa mikroba microbial. Kategori kedua adalah anaerobik, ketika mikroorganisme tidak memerlukan oksigen untuk memecah bahan organik, seringkali membentuk metana, karbon dioksida, dan biomassa berlebih excess. Dan yang ketiga adalah anoxic, ketika mikroorganisme menggunakan molekul lain selain oksigen untuk pertumbuhan, seperti untuk menghilangkan sulfat, nitrat, nitrit, selenat, dan selenit.

\section{Peranan Eceng Gondok}

Peranan Eceng Gondok dalam Pengolahan Limbah

Limbah cair industri tidak ditanggulangi secara baik maka dapat mengontaminasi dan membahayakan ekosistem di air dan sekitarnya. Maka dari itu, perlu dilakukan penanganan yang baik. Salah satu penanganan yang efektif adalah dengan tanaman air yang diketahui mampu menjadi biofiltrasi alami yang dapat mengurangi kadar bahan-bahan berbahaya pada limbah cair tersebut. Salah satunya adalah eceng gondok. 


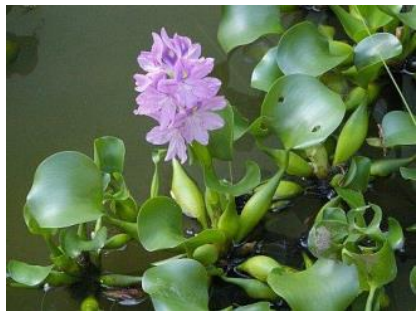

Gambar 1. Eceng Gondok

Sumber: Wikipedia.

\section{Daya Serap Eceng Gondok terhadap Logam Berat}

Muramoto dan Oki dalam Sudibyo (1989) menjelaskan, bahwa Eceng gondok dapat digunakan untuk menghilangkan polutan, karena fungsinya sebagai sistem filtrasi biologis alami, sehingga dapat menghilangkan nutrien mineral dan unsur-unsur logam berat. Penerapannya menggunakan mekanisme fitoekstraksi dan rizofiltrasi.

Mekanisme fitoekstraksi adalah penyerapan logam berat oleh akar tanaman dan mengakumulasi logam berat tersebut ke bagian-bagian tanaman seperti akar, batang, dan daun. Mekanisme rizofiltrasi adalah pemanfaatan kemampuan akar tanaman untuk mengendapkan, mengakumulasi logam berat dari aliran limbah. Mekanisme ini terjadi ketika akar tumbuhan mengabsorpsi larutan polutan sekitar akar ke dalam akar, yang selanjutnya ditranslokasi ke dalam organ tumbuhan melalui pembuluh xylem.

Hasil Penelitian yang dilaporkan oleh Hasyim (1992) bahwa kadar logam Fe menurun 3,177 ppm $(65,45$ persen) untuk satu rumpun eceng gondok, 3,511 ppm (71,93 persen) untuk dua rumpun eceng gondok dan 3,686 ppm (74,47 persen) untuk tiga rumpun eceng gondok pada wadah yang diberi $5 \mathrm{ppm}$ Fe. Begitu juga wadah yang diberi dengan timbal (Pb) 5 ppm. Kadar logam $\mathrm{Pb}$ menurun 5,167 ppm (96,4 persen) pada perlakuan satu rumpun eceng gondok, menurun 5,204 ppm (98,7 persen) pada perlakuan dua rumpun, dan menurun 6,019 ppm $(99,7$ persen) pada perlakuan tiga rumpun.

Lubis dan Sofyan (1986) menyimpulkan logam chrom ( $\mathrm{Cr}$ ) dapat diserap oleh eceng gondok secara maksimal pada pH 7. Dalam penelitiannya, logam $\mathrm{Cr}$ semula berkadar $15 \mathrm{ppm}$ turun hingga 51,85 persen. Menurut Little (1968) dan Lawrence dalam Moenandir (1990), Heider mengatakan bahwa eceng gondok mempunyai manfaat yaitu mempunyai sifat biologis sebagai penyaring air yang tercemar oleh berbagai bahan kimia buatan industri.

\section{Kemampuan Perkembangan Eceng Gondok}

Eceng gondok merupakan tumbuhan yang hidup dalam perairan terbuka. Mengapung bila air dalam dan berakar didasar bila air dangkal. Perkembangbiakan eceng gondok terjadi secara vegetative maupun secara generatif. Perkembangan secara vegetatif terjadi bila tunas baru tumbuh dari ketiak daun, lalu membesar dan akhirnya menjadi tumbuhan baru. Setiap 10 tanaman eceng gondok mampu berkembang biak menjadi 600.000 tanaman baru dalam waktu 8 bulan. Dengan perkembangan yang cepat dan kemampuan penyerapan nutrien dalam jumlah besar mengakibatkan eceng gondok dapat dimanfaatkan untuk pengolahan air limbah. Eceng gondok dapat mencapai ketinggian antara $40-80 \mathrm{~cm}$ dengan daun yang licin dan panjangnya 7 - $25 \mathrm{~cm}$. Tumbuhan eceng gondok terdiri atas helai daun, pengapung, leher daun, ligula, akar, akar rambut, ujung akar, dan stolon yang dijadikan sebagai tempat perkembangbiakan vegetatif.

Beberapa kerugian akibat pertumbuhan eceng gondok yang tidak terkendali dapat 
menyebabkan meningkatnya evapotranspirasi (penguapan dan hilangnya air melalui daun-daun tanaman) karena daun-daunnya yang lebar dan serta pertumbuhannya yang cepat. Menurunnya jumlah cahaya yang masuk kedalam perairan sehingga menyebabkan menurunnya tingkat kelarutan oksigen dalam air (DO: Dissolved Oxygens). Tumbuhan eceng gondok yang sudah mati akan turun ke dasar perairan sehingga mempercepat terjadinya proses pendangkalan. Mengganggu lalu lintas (transportasi) air, khususnya bagi masyarakat yang kehidupannya masih tergantung dari sungai seperti di pedalaman Kalimantan dan beberapa daerah lainnya. Meningkatnya habitat bagi vektor penyakit pada manusia. Dan dapat mengurangi keanekaragaman spesies yang tumbuh di perairan.

\section{Peranan Eceng Gondok dalam Industri Kerajinan}

Eceng gondok sering dianggap sebagai tanaman liar yang mengganggu ekosistem di bawah air. Tanaman ini tumbuh lebat dan tidak terkendali sehingga sering menggangu jalur transportasi perairan. Tetapi, dibalik hal tersebut tersimpan beberapa manfaat yang cukup berguna untuk kehidupan manusia. Dari segi ekonomi ternyata enceng gondok ini dapat menjadi bahan baku dalam pembuatan berbagai kerajinan tangan.

Masyarakat sekarang ini sering memanfaatkan eceng gondok untuk dianyam menjadi sebuah kerajinan tangan. Kerajinan eceng gondok memiliki sifat yang elastis, kuat dan ringan sehingga daun dan batang eceng gondok yang sudah dikeringkan mudah dianyam menjadi tirai, tas, sandal, perabotan rumah, penyekat ruang dan lain sebagainya. (Susilowati, 2012)
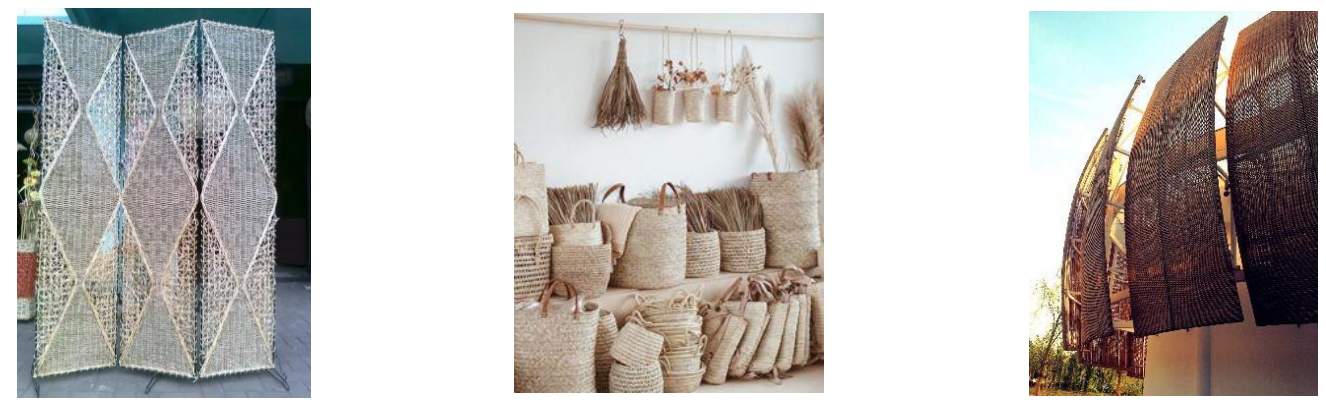

Gambar 2. Hasil kerajinan (tas sandal, penyekat ruang \& fasad bangunan)

Sumber: Akurat.co.

Adapun proses pengolahan eceng gondok menjadi sebuah kerajinan dengan cara daun dan batang eceng gondok dipisahkan, lalu dikumpulkan. Kemudian di jemur \pm 4 hari hingga warnanya menjadi coklat tua. Untuk batang eceng yang ingin diwarnain, cukup dengan merebus batang enceng gondok sampai mendidih dan dicampurkan pewarna pakaian sesuai warna yang diinginkan. Jemur kembali batang eceng gondok yang berwarna selama 1 minggu agar lebih ulet dan bebas dari jamur. Setelah menjemur, eceng gondok digilas lalu eceng sudah dapat diolah atau dianyam (Wardiah, 2019).

\section{METODE}

\section{Tahap Perancangan}

Tahap ini dimulai dari pemilihan isu tingginya aktivitas industri sawit yang menyebabkan terganggunya ekosistem Sungai Siak akibat adanya logam berat. Pemilihan tapak dilihat dari lokasi yang berada di pinggir Sungai Siak. Selanjutnya melakukan analisa tapak lalu mengidentifikasi masalah yang ada di tapak eksisting, dan mencari solusi ruang untuk masuk ke dalam perancangan. Kemudian pengusulkan program edukasi terhadap pemanfaatan potensi eceng gondok sebagai biofiltrasi alami yang dapat mempurifikasi logam berat pada kandungan 
air di Sungai Siak sebesar 99,70\%. Lalu, pembagian zoning dalam proyek dan yang terakhir hasil dari perancangan.

\section{Metode Perancangan}

Lokasi proyek berada di Kabupaten Siak yang terkenal akan budaya melayu dan merupakan tempat wisata kebudayaan siak. Maka dari itu, perancangan proyek ini menggunakan penggabungan metode perancangan lokalitas dan kontekstual.

Metode Lokalitas adalah upaya keruangan yang tetap memperhatikan keaslian dari sebuah produk keruangan masa lalu. Metode Kontekstual adalah sebuah basis penghormatan terhadap tradisi yang sudah ada sebelumnya (Susanto, 2020). Dengan mengkombinasi kedua metode tersebut diharapkan proyek dapat selaras, serasi, seimbang dan senada terhadap lokalitas unsur siak di Kabupaten Siak. Dengan penggabungan unsur vernacular dan modern, seperti penggunaan material lokal dan stuktur baja, kesan interior yang minimalis dan modern yang membuat proyek ini tetap menjaga unsur kebudayaan siak dan tidak ketinggalan zaman.

\section{Metode Penyusunan Program Aktivitas}

Program yang diusulkan adalah yang berhubungan dengan pengolahan air Sungai Siak yang tercemar akibat logam berat dengan memanfaatkan potensi eceng gondok sebagai biofiltrasi alami yang dapat mempurifikasi logam berat pada kandungan air di Sungai Siak dan permasalahan dan kondisi eksisting Kabupaten Siak.

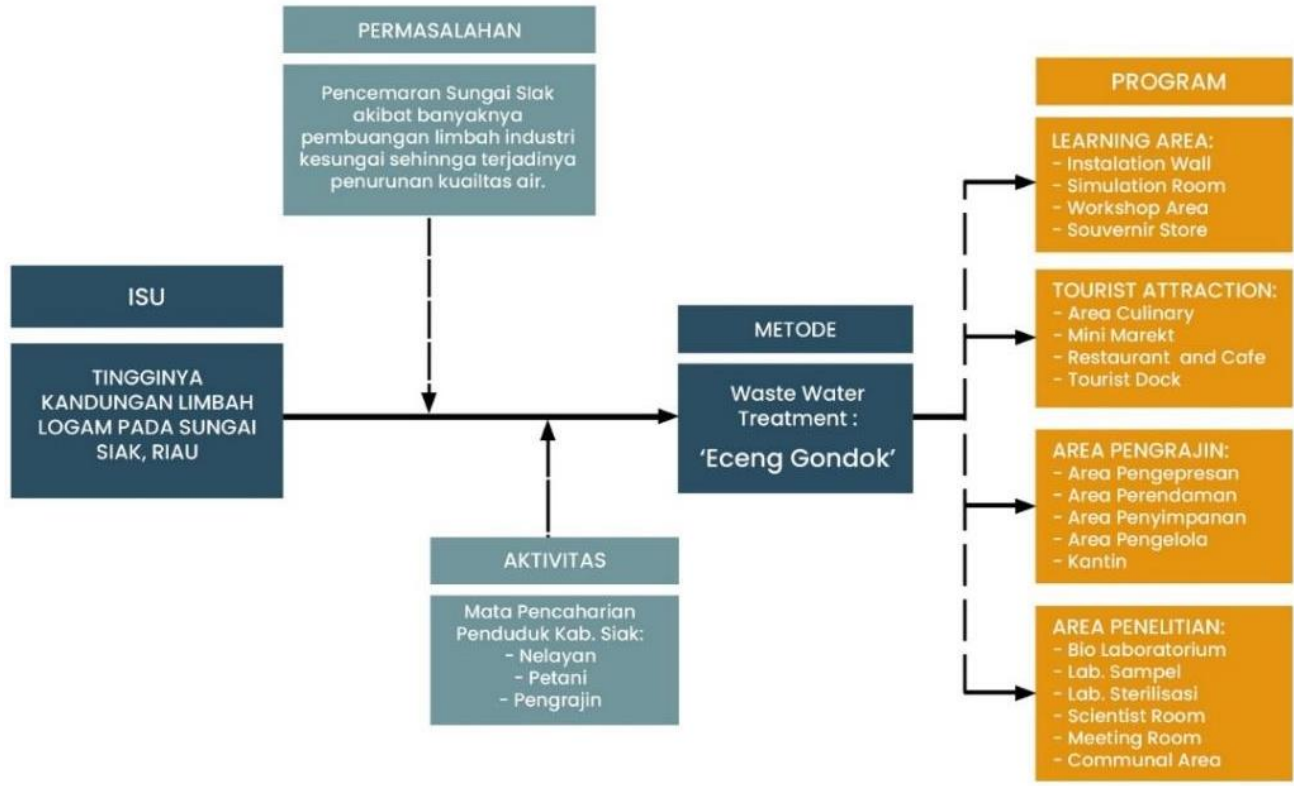

Gambar 3. Skema Pemikiran Program Sumber: Dokumentasi Pribadi, 2021

\section{Mekanisme}

Pemanfaatan kemampuan filtrasi biologis oleh eceng gondok dapat dilakukan dalam penerapan fitromediasi dan rhizofiltrasi yang dapat menyerap 99,7\% kandungan logam berat pada Sungai Siak. Namun, eceng gondok dapat berkembang biak dengan sangat cepat yang dapat menurunkan jumlah cahaya yang masuk ke dalam perairan sehingga menyebabkan menurunnya tingkat kelarutan oksigen dalam air (DO: Dissolved Oxygens). Maka dari itu, perlu dilakukan penyortiran untuk menjaga kelangsungan perkembangan eceng gondok sehingga tidak mengganggu mekanisme filtrasi pada kolam mediasi. 
Eceng gondok yang sudah terkontaminasi oleh logam berat akan berubah warna menjadi hijau pucat. Lalu akan disortir, dikeringkan dan diolah menjadi produk kerajinan, fasad bangunan dan instalasi keruangan.

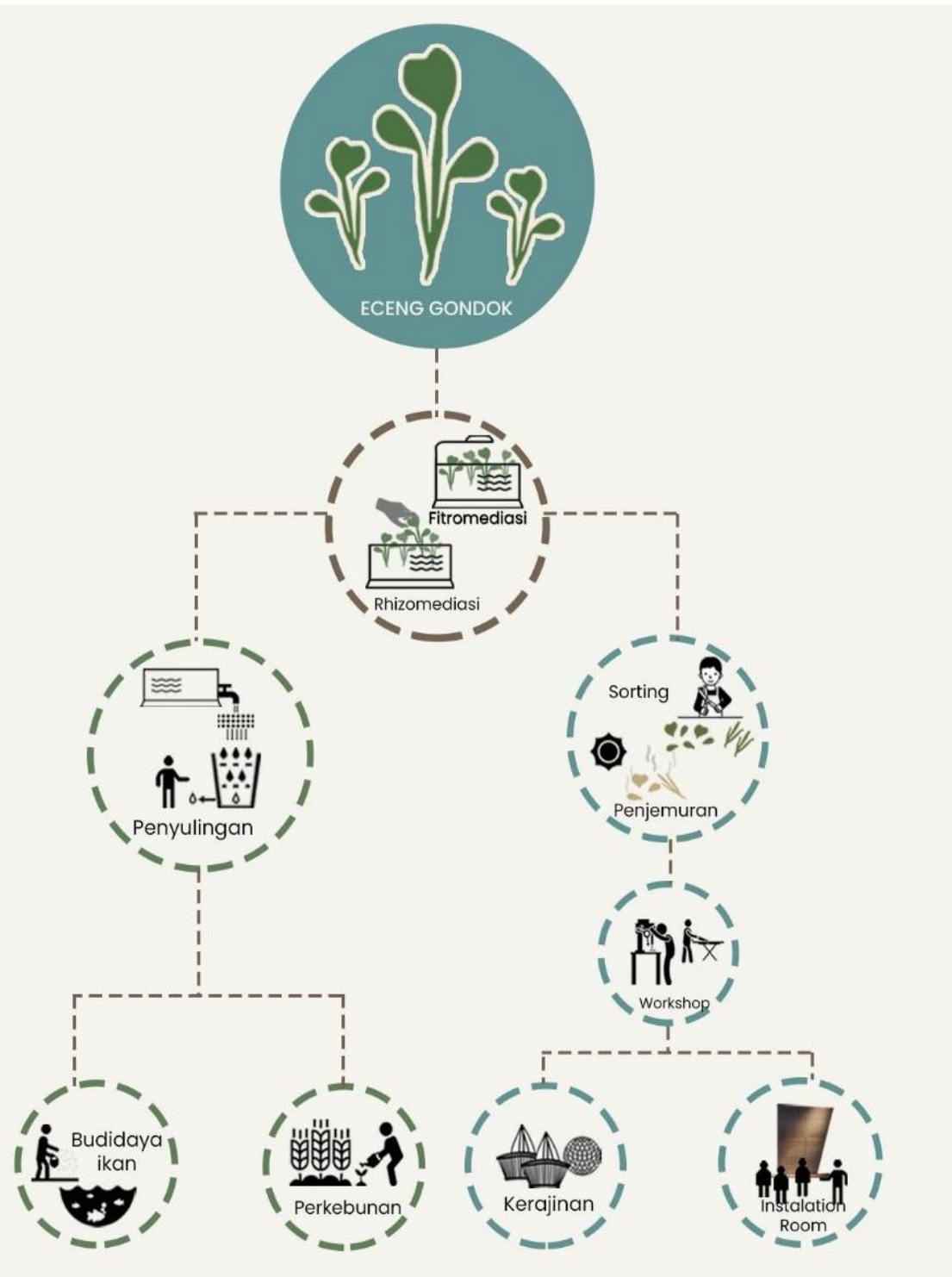

Gambar 4. Diagram Mekanisme

Sumber: Chou, 2021

\section{DISKUSI DAN HASIL}

Kabupaten Siak adalah salah satu kabupaten di Provinsi Riau. Terdapat Sungai Siak yang membelah Kabupaten Siak. Menurut ANTARA News (2018), kualitas air di Sungai Siak bagian hilir yang bermuara sepanjang Kabupaten Siak sudah termasuk dalam kategori tercemar logam berat dan tidak bisa dipergunakan untuk aktivitas sehari-hari bagi masyarakat dan menurut Budijono et al (2017) Sungai Siak sudah tercemar logam berat sebesar 0,211 mg/L. 


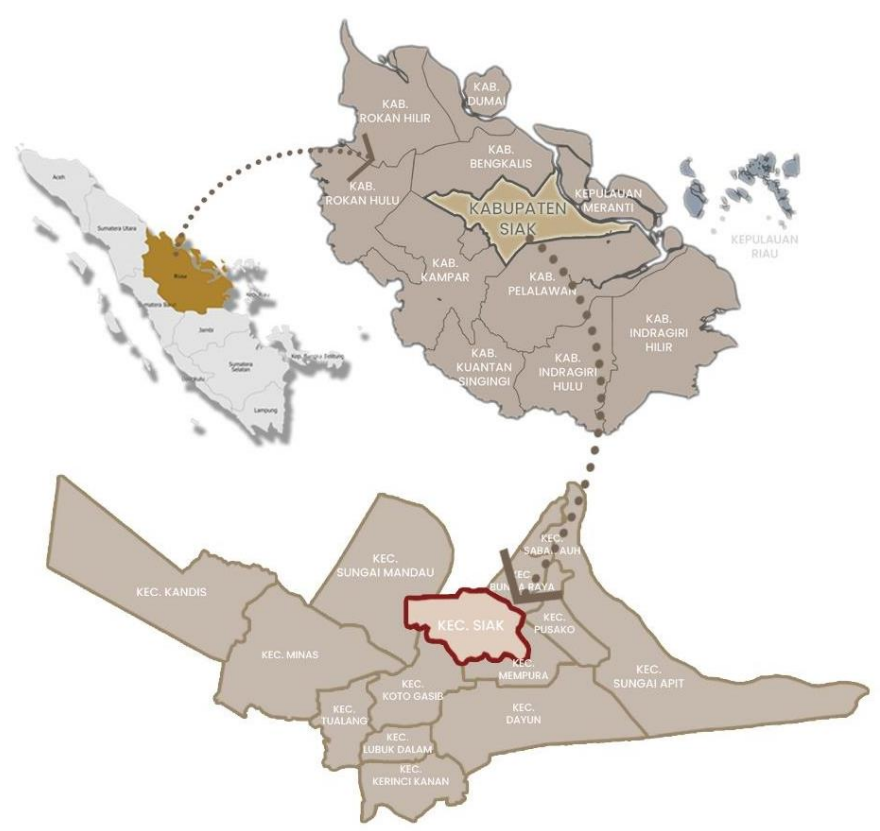

Gambar 5. Peta Letak Kabupaten Siak Sumber: Chou, 2021

\section{Data Tapak:}

1. Kawasan pusat peradaban kebudayaan melayu di Indonesia.

2. Terdapat Kesultanan Siak Sri Indrapura (Kerajaan Melayu Islam), Jarak ke Kerajaan Slak Indrapura $\pm 2.8 \mathrm{~km}$

3. Dilalui oleh Jalan Lintas: Jalan Buatan-Siak yang menghubungkan Kabupaten Siak ke kota Pekanbaru.

4. Berseberangan dengan Masjid Sultan Syarif Hasyim (Cagar Budaya).

5. Berseberangan dengan Taman Tengku Agung (Wisatawan).

\section{Lokasi Tapak}

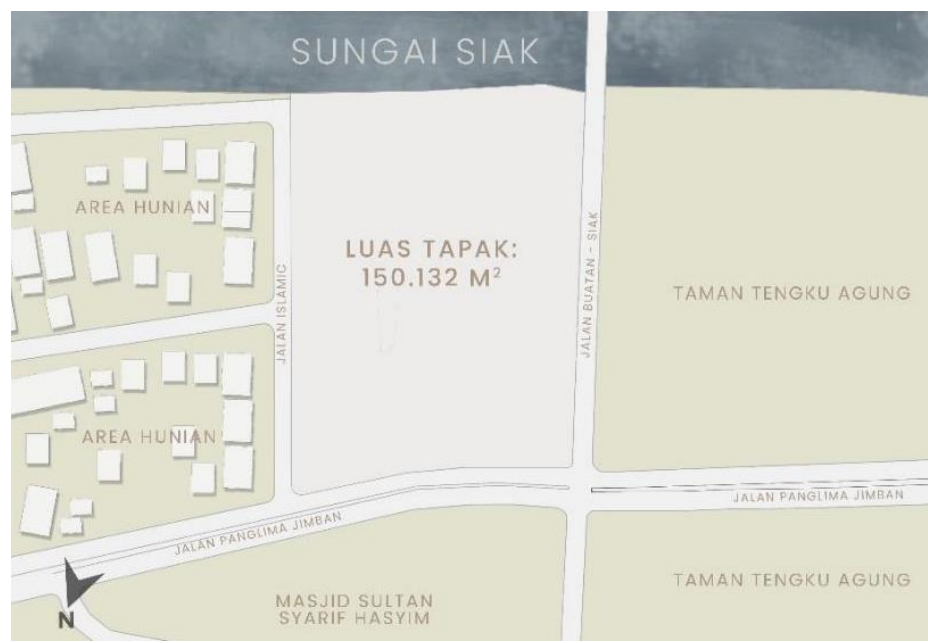

Gambar 6. Lokasi Tapak

Sumber: Chou, 2021 
Tabel 1. Data Lokasi Tapak

\begin{tabular}{ccc} 
NO. & PARAMETER & KET. \\
\hline 1 & LUAS TAPAK & 1,5 ha \\
\hline 2 & KDB & 50 \\
\hline 3 & KLB & 2 \\
\hline 4 & KDH & 20 \\
\hline 5 & KB & 2 \\
\hline 6 & KTB & 0 \\
\hline
\end{tabular}

Sumber: Peraturan Daerah Kota Pekanbaru (2010)

\section{Analisis Tapak dan Transformasi Gubahan}
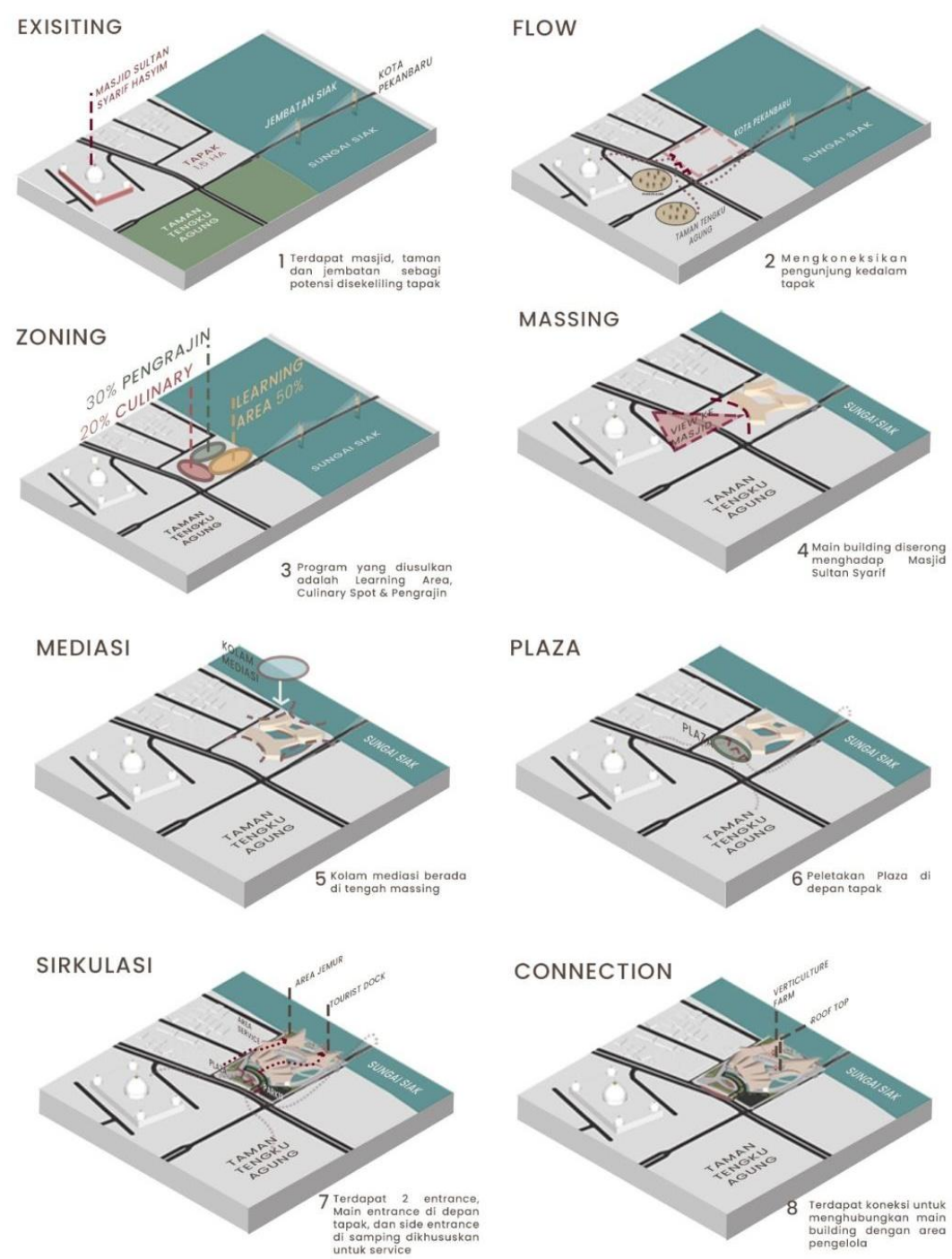

Gambar 7. Analisis Tapak Sumber: Chou, 2021 
Setelah menganalisis tapak dan transformasi massa, selanjutnya adalah penyesuaian bersifat lebih kecil ke dalam ruang-ruang yang ada. Dengan memperhatikan ruang gerak dan aktivitas manusia di dalamnya lalu menyesuaikan standard yang didapatkan dari buku Time Saver Standards, Human Dimension dan Architect's Data.

\section{D EXPLODED}

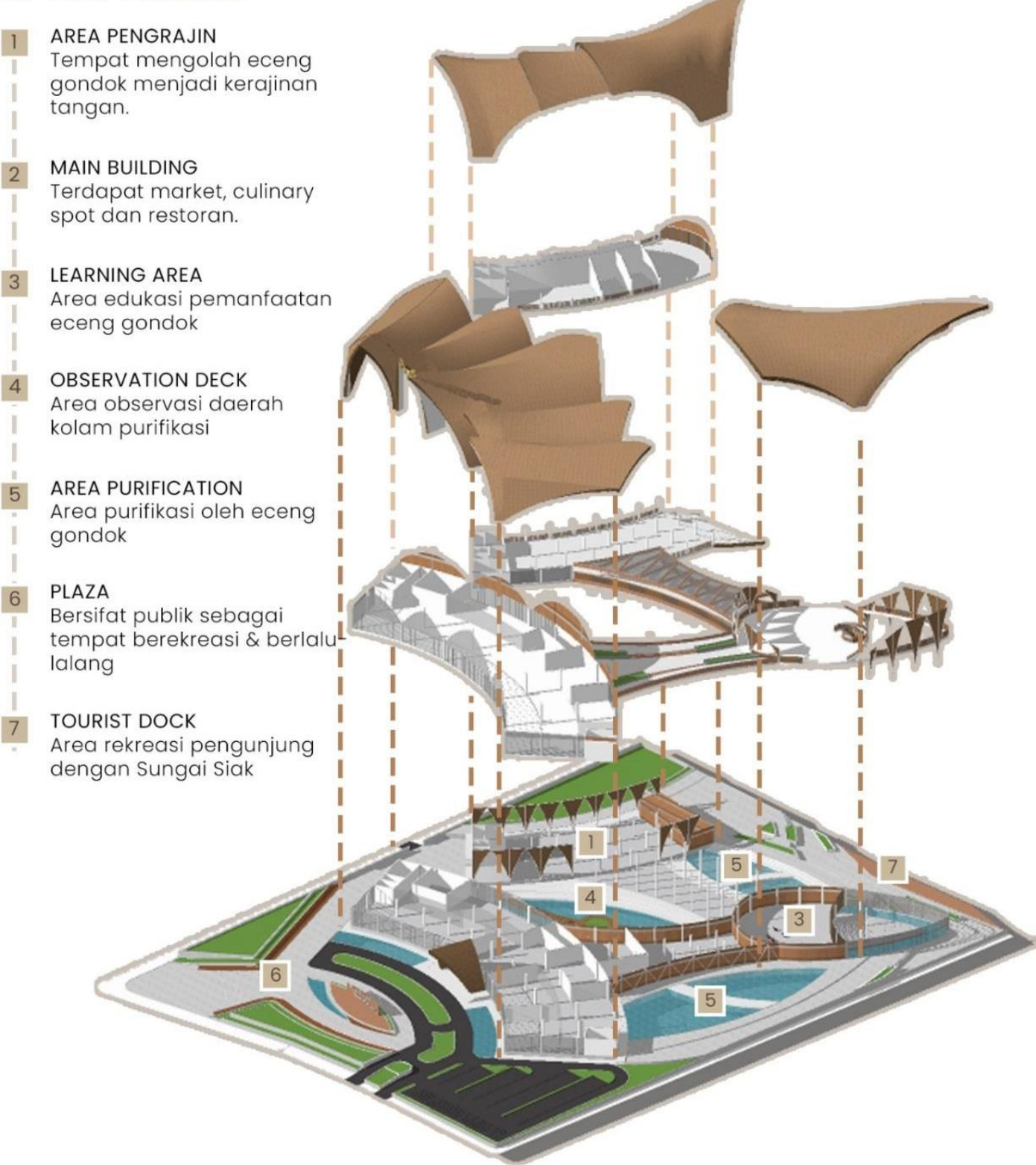

Gambar 8. 3D Exploded

Sumber: Chou, 2021

Pada gambar potongan perspektif (gambar 8) dibawah dapat dilihat bahwa area atau kolam mediasi (mekanisme fitromediasi dan rhizofiltrasi) mengelilingi bangunan, yang fungsinya untuk mengolah air Sungai Siak yang mengandung logam berat menjadi layak digunakan untuk keperluan dan pemakaian verticulture farm dan budidaya ikan pada bangunan. Adapun ruangruangan di dalam bangunan memanfaatkan suasana semi-outdoor dan nyaman sehingga para pengunjung dapat melakukan banyak aktivitas pada bangunan ini. Tingginya plafon pada area culinary di main building, diharapkan pengunjung merasakan keruangan yang luas dan nyaman 
pada saat berkumpul dan menyantap makanan.
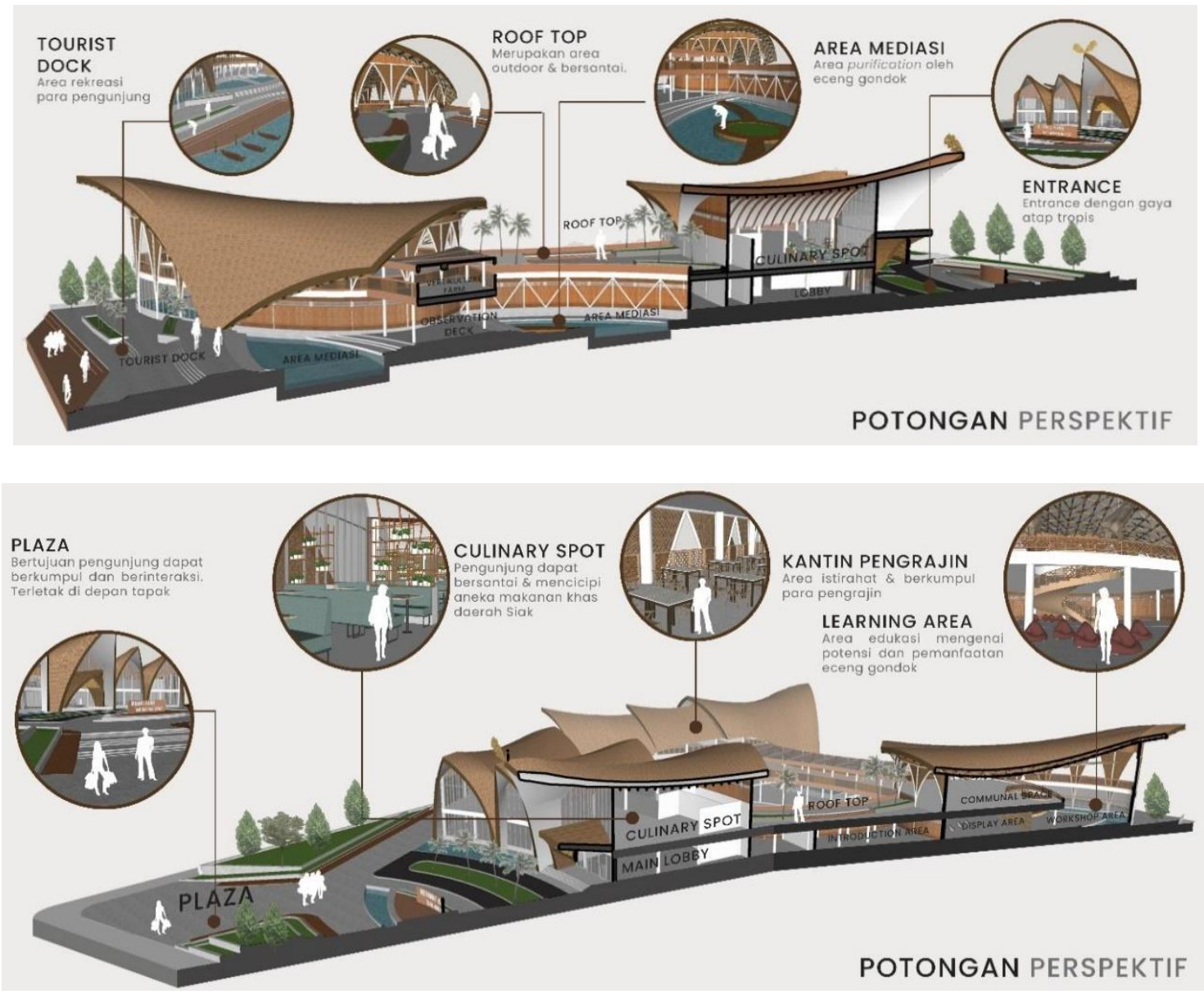

Gambar 9. Potongan Perspektif

Sumber: Chou, 2021

Gambar 10 merupakan gambaran suasana bangunan melalui perspektif eksterior. Dapat dilihat bahwa eceng gondok diubah menjadi fasad pada bangunan. Bentuk atap bangunan juga mengadaptasi bentukan atap rumah adat khas siak yang bertujuan untuk tetap mempertahankan unsur lokalitas dan kontekstual pada bangunan. 

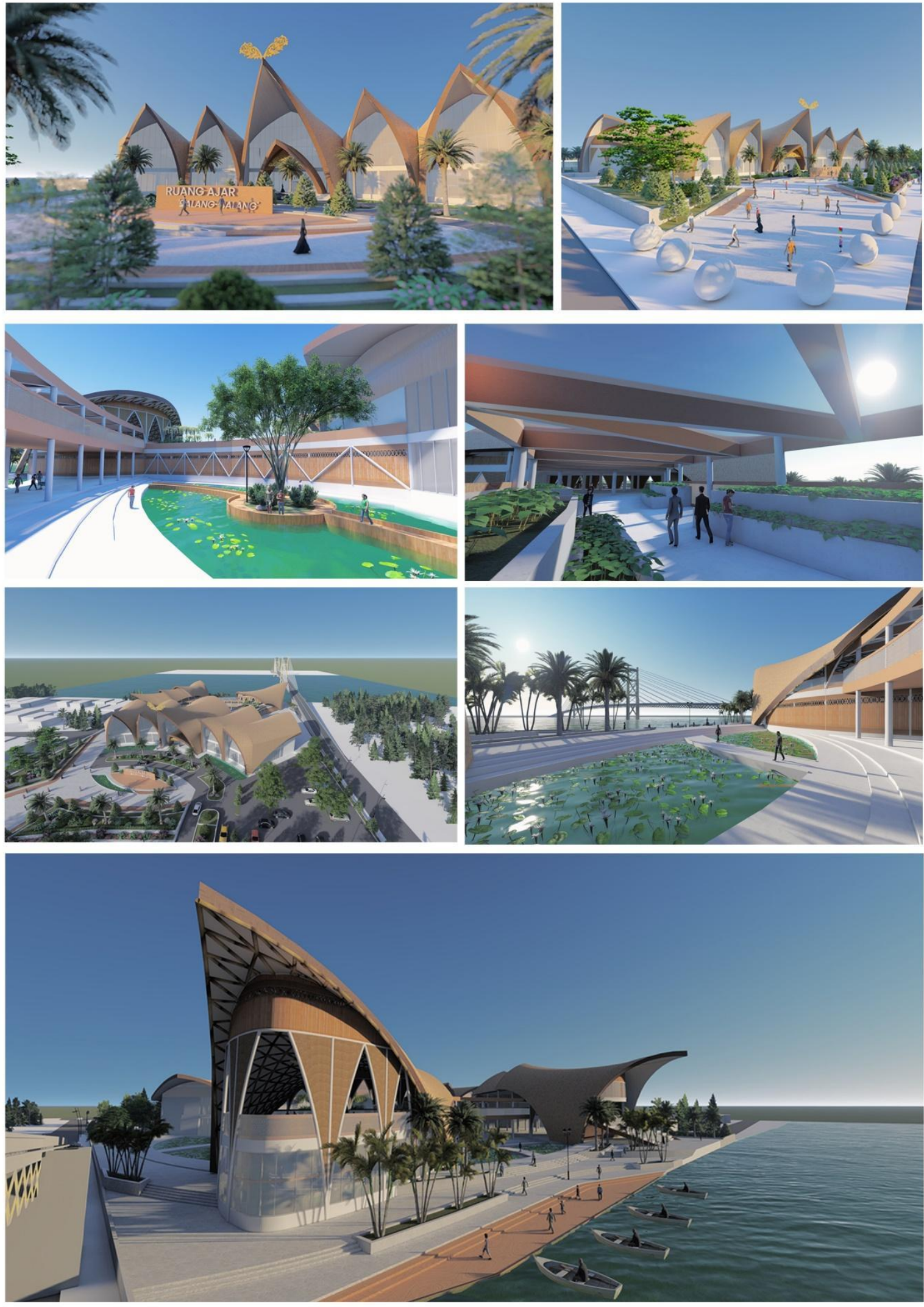

Gambar 10. Perspektif Eksterior

Sumber: Chou, 2021 

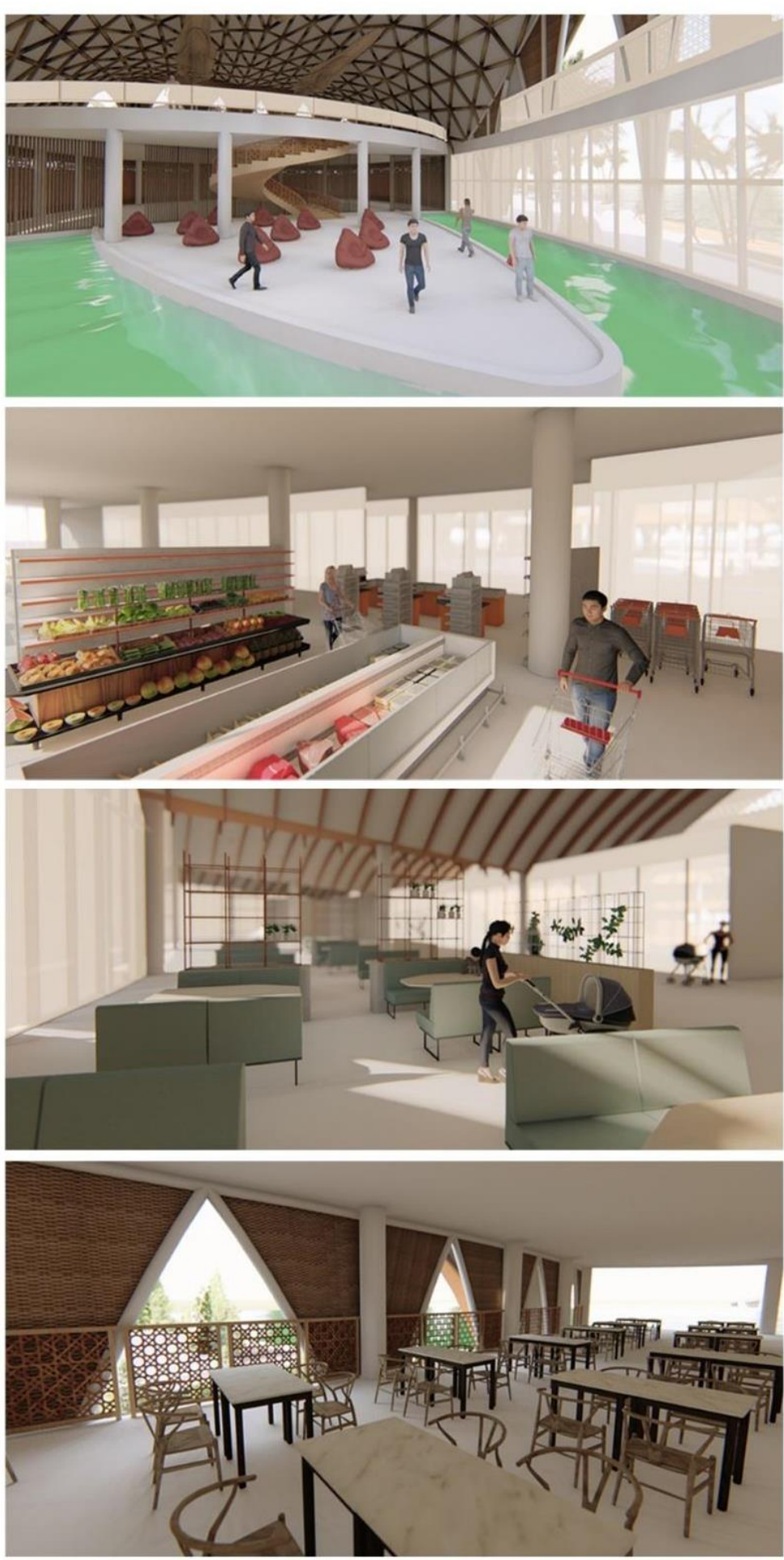

Gambar 11. Perspektif Interior Sumber: Chou, 2021

Gambar 11 merupakan suasana perspektif interior. Dapat dilihat eceng gondok diolah menjadi railing tangga pada learning area. Permainan material alami seperti material eceng gondok dan bambu ekspos diharapkan dapat membuat pengunjung merasakan keruangan yang baru dan nyaman 


\section{KESIMPULAN DAN SARAN}

Kesimpulan

Ruang Ajar Balang-balang merupakan pusat edukasi eceng gondok sebagai purifikasi logam berat di Sungai Siak, Riau. Keseluruhan bangunan mulai dari program hingga peletakan zoning bentukan massa merepresentasikan sebuah bangunan yang mengedukasi pengunjung terhadap potensi eceng gondok. Mulai dari eceng gondok sebagai biofiltrasi alami, mengolah menjadi kerajinan tangan dan instalasi ruang dengan tujuan mengendalikan perkembangan eceng gondok yang pesat dan memanfaatkan air hasil filtrasi pada budidaya ikan dan verticulture farm. Bentukan bangunan yang melengkung mengikuti bentukan dari kolam mediasi, sehingga bentuk bangunan dapat seirama dengan bentukan kolam dan tidak kaku atau monoton. Adapun ruangruangan yang menggunakan konsep semi-outdoor dengan permainan material bambu ekspos diharapkan dapat membuat pengunjung merasakan keruangan yang baru dan nyaman dalam konsep bangunan yang menggunakan unsur kebudayaan siak. Diharapkan proyek ini dapat mengedukasi masyarakat sekitar dalam memanfaatkan potensi eceng gondok sebagai biofiltrasi alami, kerajinan tangan, dan instalasi keruangan.

\section{Saran}

Diperlukan kerjasama antara pengelola bangunan dengan institusi pendidikan dan institusi lain di sekitar agar fungsi edukasi dapat berjalan dengan baik dan juga pentingnya peran aktif dan inovatif dalam merancang bangunan yang ramah lingkungan. Dengan hadirnya proyek ini, semoga bisa menjadi wadah edukasi dalam pemanfaatan eceng gondok dan menjadikan proyek ini sebagai referensi untuk perancangan kedepannya.

\section{REFERENSI}

Ariful, T. (2017, Mei 09). Kedalaman Sungai Siak Semakin Dangkal. Retrieved from Riauone,com: https://riauone.com

Frick, H. (2007). Dasar-dasar Arsitektur Ekologi. Yogyakarta.

Mahdi, S. (2019, Oktober 29). Mengenal Lebih Dekat Enceng Gondok yang Multi Fungsi. Retrieved from Kompasiana Beyond Blogging: https://www.kompasiana.com/yeddi/5db84a9e097f367d9146b942/mengenal-lebihdekat-enceng-gondok-yang-multi-fungsi?page=all

Peraturan Daerah Kota Pekanbaru. (2010). Peraturan Daerah Kota Pekanbaru Nomor 1 Tahun 2010 tentang Retribusi Izin Mendirikan Bangunan Dengan Rahmat Tuhan Yang Maha Esa Walikota Pekanbaru. Pekanbaru, Riau, Indonesia.

Rosida, I. I. (2018). Kandungan Logam Berat Pb pada Air, Sedimen dan Daging Ikan Juaro (Pangasius polyuranodon Blkr) di Perairan Sungai Siak Desa Teluk Mesjid Kecamatn Sungai Apit. 1-7.

Susanto, A. (2020). Research by Desain. Jakarta.

Susilowati, A. (2012). Peranan Pendapatan Industri Kerajinan Eceng Gondok Terhadap Total Pendapatan Rumah Tangga Pengrajin di Desa Depok.

Sutanto, A. (2020). In Peta Metode Desain. Jakarta.

Titisari, E. Y. (2012). Konsep Ekologis pada Arsitektur. Jurnal RUAS, Volume 10 NO 2, Desember 2012, ISSN 1693-3702, 10, 20-31.

Wardiah, I. (2019). Pemanfaatan Eceng Gondok untuk Pemberdayaan Ekonomi Masyarakat di Desa Jelapati Kabupaten Barito Kuala. 152-160. 